\title{
Mouse Chromosome 3
}

\section{Miriam H. Meisler* and Michael F. Seldin}

Received June 10, 1991

\section{Introduction}

Mouse Chromosome (Chr) 3 is marked by more than 50 molecular markers and several interesting mutant genes. Conserved regions with homology to human chrs 1p, 4q, and 8 have been defined. The conserved regions include two multigene families, amylase and carbonic anhydrase. Physical mapping on pulse-field gels has demonstrated conservation of certain intergenic distances on mouse $\mathrm{Chr} 3$ and human chr 1 . This report presents a new composite map of $\mathrm{Chr} 3$. In addition, we have recommended for inclusion in future crosses five reference loci which span the linkage map and which can be typed by restriction fragment length variation (RFLV) and polymerase chain reaction (PCR). Widespread utilization of these reference loci would contribute to the generation of reliable composite maps in the future.

\section{The mouse Chr 3 map}

The map of mouse Chr 3 was generated by M.F. Seldin using data from crosses between inbred laboratory strains, interspecific crosses and recombinant inbred (RI) strains. A locus list including citations to the linkage data on which the map is based is presented in Table 1. The composite map is represented in Fig. 1. Map distances are measured from the centromere, based on the estimated distance from the centromere to Car-1, which was determined with a Robertsonian translocation chromosome (Davisson et al. 1976). The framework of the map was based on recombination data for the loci Car-1, Evi-1, Amy-2 and Egf, obtained from four backcrosses. The major source of deviation between this map and the map generated by The Jackson Laboratory is due to the current estimate that the Evi-1 to Amy-1 distance is $39 \mathrm{cM}$, in contrast to the previous value of $54 \mathrm{cM}$. (Measurements of this dis-

* Chair of Committee for Mouse Chromosome 3

Offprint requests to: Miriam $\mathrm{H}$. Meisler, Department of Human Genetics, University of Michigan, Ann Arbor, MI 48109-0618, USA. tance vary from $27-53 \mathrm{cM}$ in the four backcrosses cited in Table 1). The positions of Gba, Es26 and Es27 have been corrected, and small changes in the positions of several other loci are indicated. It should be emphasized that map positions are approximate, and that the order of closely linked genes which have not been typed in the same cross is uncertain.

Since recombination frequencies vary in different crosses, the composite map may distort the order of loci which were not mapped in the same backcross. In deriving the composite map, data from RI strains was used to determine gene position as a supplement to backcross data. For a fuller discussion of the method used to generate the map, the reader is referred to the discussion in the Mouse Chromosome 1 Committee Report.

Three linkage groups on mouse Chr 3 are conserved in the human genome

All of the genes mapped to the region between $G b a$ and $A m y-2$ are conserved on human chr 1, with the exception of $C s \mathrm{fm}$, which is on human chr $5 \mathrm{q}$ (Mosely and Seldin 1989; Buchberg et al. 1989). Physical mapping of five loci from this linkage group demonstrated conservation of gene order and intergenic distance in the two species (Kingsmore et al. 1990). The $10 \mathrm{cM}$ region between Fabpi and Egf is conserved on human chr 4q. The carbonic anhydrase genes, Car-1, Car-2 and Car-3, are linked on human chr 8; no other loci have yet been mapped to this conserved group.

The structures of the amylase gene clusters in human and mouse are quite different. In mouse, the salivary amylase gene is located $21 \mathrm{~kb}$ upstream of a pancreatic amylase gene (Wiebauer et al. 1985). In the 230 kb human gene cluster, the two pancreatic amylase genes are located upstream of the three salivary amylase genes, and several copies of an endogenous retrovirus and an actin pseudogene are interspersed with the amylase genes (Samuelson et al. 1990). The human genes were derived from a single pancreatic amylase gene during primate evolution. The adjacent retrovirus is required for tissue-specific expression of human salivary amylase (Ting and Meisler, unpublished data). 
Table 1. Mouse Chr 3 loci.

\begin{tabular}{|c|c|c|c|c|}
\hline Locus $^{\mathrm{a}}$ & Name & Map $^{b}$ & $\begin{array}{l}\text { Method of } \\
\text { Analysis } \mathrm{c}^{\mathrm{c}, \mathrm{d}}\end{array}$ & Reference \\
\hline$A c r b-2$ & acetylcholine receptor $\beta-2$ neural & 39.6 & $\mathrm{C}: 3$ & Bessis et al. 1990 \\
\hline Acts & $\begin{array}{l}\text { skeletal } \alpha \text { actin; the mouse } \\
\text { skeletal } \alpha \text { actin clone detects } \\
\text { sequences that map to mouse } \\
\text { Chr } 18 \text { (Howard et al. 1990) }\end{array}$ & $\mathrm{X}$ & C: somatic cell & Czosnek et al. 1982 \\
\hline$A d h-1$ & alcohol dehydrogenase- 1 & 72.1 & $\mathrm{~B}: 3,8,13 ; \mathrm{C}: 9$ & $\begin{array}{l}\text { Chapman et al. 1979; Bonhomme et } \\
\text { al. 1979; Holmes et al. 1981; Ceci } \\
\text { et al. 1987; Gisselbrecht et al. } 1989\end{array}$ \\
\hline Adh-1ps & $\begin{array}{l}\text { alcohol dehydrogenase-1 } \\
\text { pseudogene }\end{array}$ & 56.0 & $\mathrm{C}: 9$ & Ceci et al. 1987 \\
\hline$A d h-1 t$ & alcohol dehydrogenase-temporal & 72.1 & B:14 & Balek et al. 1982; Holmes et al. 1983 \\
\hline$A d h-3$ & alcohol dehydrogenase-3 & 72.1 & $\mathrm{~B}: 7,8,9,10,13$ & $\begin{array}{l}\text { Holmes et al. 1981a, 1981b and } \\
\text { 1981c; Duley and Holmes } 1982 \text {; } \\
\text { Prochazka et al. 1985; Holmes et } \\
\text { al. 1985; Mucenski et al. } 1988\end{array}$ \\
\hline$A d h-3 t$ & $\begin{array}{l}\text { alcohol dehydrogenase- } \\
\text { 3-temporal }\end{array}$ & 72.1 & B:13 & Holmes et al. $1979,1981 \mathrm{c}$ \\
\hline Adh -5 & alcohol dehydrogenase- 5 & $\mathrm{X}$ & somatic cell & Giri et al. 1989 \\
\hline$A h r-1$ & aldehyde reductase- 1 & 72.1 & $\mathrm{~B}: 7,13$ & Duley and Holmes 1982 \\
\hline Ampd-I & AMP deaminase-1 (muscle form) & 51.4 & $\mathrm{C}: 1$ & Kingsmore et al. 1989 \\
\hline Ampd-2 & $\begin{array}{l}\text { AMP deaminase-2 (nonmuscle } \\
\text { form) }\end{array}$ & 54.2 & $\mathrm{C}: 1$ & Moseley et al. 1990 \\
\hline Amy-I & amylase- 1, salivary & 53.6 & $\begin{array}{l}\mathrm{B}: 3,5,8,9 ; 13 \\
\mathrm{C}: 7,9,10,11\end{array}$ & $\begin{array}{l}\text { Lane and Eicher 1979; Bonhomme et } \\
\text { al. 1979; Eicher and Lane 1980; } \\
\text { von Diemling et al. 1984; Paul and } \\
\text { Elliott 1987; Blatt et al. } 1988\end{array}$ \\
\hline$A m y-2$ & amylase- 2 pancreatic & 53.6 & $\begin{array}{l}\text { B: } 9 \\
\text { C: } 1,2,7,9,10,11\end{array}$ & $\begin{array}{l}\text { Bloor and Meisler 1980; Paul and } \\
\text { Elliott 1987; Blatt et al. 1987; } \\
\text { Moseley and Seldin } 1989\end{array}$ \\
\hline Ap2 & adipocyte protein aP2 & 4.6 & $\mathrm{~B}: 9,12$ & Heuckeroth et al. 1987 \\
\hline Arnt & $\begin{array}{l}\text { aryl hydocarbon receptor nuclear } \\
\text { translator }\end{array}$ & $\mathrm{X}$ & somatic cell & Brooks et al. 1989 \\
\hline Atplal & $\mathrm{Na}, \mathrm{K}$ ATPase $\alpha-1$ & 51.3 & $\mathrm{C}: 1,14$ & $\begin{array}{l}\text { Kent et al. 1987; Moseley and Seldin } \\
\text { 1989; Kingsmore et al. } 1990\end{array}$ \\
\hline$($ Atpa-I) & see Atplal & & & \\
\hline$B m n$ & $\begin{array}{l}\beta \text {-mannosidase activity (liver, } \\
\text { kidney) }\end{array}$ & 72.1 & $\mathrm{~B}: 9$ & Lundin 1987 \\
\hline Cacy & calcyclin & 46.9 & $\mathrm{C}: 1$ & $\begin{array}{l}\text { Moseley and Seldin 1989; Kingsmore } \\
\text { et al. } 1990\end{array}$ \\
\hline Calll & calpactin I light chain & 46.9 & $C: 9,10,12$ & $\begin{array}{l}\text { Saris et al. 1987; van Heynegen et al. } \\
\quad 1989\end{array}$ \\
\hline Capl & $\begin{array}{l}\text { calcium binding protein, } \\
\text { placental }\end{array}$ & 46.9 & $\mathrm{C}: 9,10$ & van Heynegen et al. 1989 \\
\hline Car-I & carbonic anhydrase-1 & 4.6 & B:14 & Eicher et al. 1976 \\
\hline Car-2 & carbonic anhydrase- 2 & 4.6 & $\begin{array}{l}\mathrm{B}: 3,7,8,9,10,12,14 \\
\mathrm{C}: 1\end{array}$ & $\begin{array}{l}\text { Eicher et al. 1976; Bonhomme et al. } \\
\text { 1979; Elliot 1979; von Diemling et } \\
\text { al. 1984; Paul and Elliott 1987; } \\
\text { Novak et al. 1988; Moseley and } \\
\text { Seldin 1989; Copeland and Jenkins } \\
1990\end{array}$ \\
\hline Car-3 & carbonic anhydrase- 3 & 7.0 & $\mathrm{C}: 14$ & Beachey et al. 1990 \\
\hline$C d I$ & cluster designation 1 & 46.6 & $C: 1$ & Moseley et al. 1990 \\
\hline$C d 2$ & cluster designation 2 & 50.4 & $\mathrm{C}: 1$ & $\begin{array}{l}\text { Moseley and Seldin 1989; Kingsmore } \\
\text { et al. } 1990\end{array}$ \\
\hline$c d m$ & cadmium resistance & 65.6 & A:9 & Taylor et al. 1973; Taylor et al. 1976 \\
\hline Cnp-2 & $\begin{array}{l}\text { cyclic nucleotide } \\
\text { phosphodiesterase-2 }\end{array}$ & 42.8 & $\mathrm{C}: 9,11$ & Bernier et al. 1988 \\
\hline$c o a$ & cocoa & 8.5 & A: 14 & $\begin{array}{l}\text { Sweet and Prochazka 1985; Novak et } \\
\text { al. } 1988\end{array}$ \\
\hline Csfm & $\begin{array}{l}\text { colony stimulating factor, } \\
\text { macrophage }\end{array}$ & 52.4 & $\mathrm{C}: 2,3$ & $\begin{array}{l}\text { Gisselbrecht et al. 1989; Buchberg et } \\
\text { al. } 1989\end{array}$ \\
\hline$D 3 N d s I$ & DNA segment, Chr 3 & 33.3 & $\mathrm{C}: \underline{4}$ & Unpublished data \\
\hline D3Tu33 & $\begin{array}{l}\text { DNA segment. Chr } 3 \\
\text { Tubingen-33 (previously } \\
\text { D17Tu33) }\end{array}$ & 61.9 & $\mathrm{C}: \overline{1} 2$ & $\begin{array}{l}\text { Vincek et al. } 1989 \text { (originally } \\
\text { designated D17Tu33, but data more } \\
\text { consistent with Chr } 3 \text { localization) }\end{array}$ \\
\hline D3Tu5I & $\begin{array}{l}\text { DNA segment, Chr } 3 \\
\text { Tubingen- } 51\end{array}$ & 46.9 & $\mathrm{C}: \underline{1}, 9,10,12$ & $\begin{array}{l}\text { Vincek et al. } 1989 \text { (originally } \\
\text { designated DITTu51, but } \\
\text { subsequent data has established } \\
\text { localization to Chr } 3 \text { ) }\end{array}$ \\
\hline
\end{tabular}


Table 1. Continued.

\begin{tabular}{|c|c|c|c|c|}
\hline$d e$ & droopy ear & 52.4 & $A: 5,13,14$ & $\begin{array}{l}\text { Curry 1959; Lane 1980; Lane and } \\
\text { Eicher 1979; Holmes et al. } 1981\end{array}$ \\
\hline$E g f$ & epidermal growth factor & 66.1 & $C: 1,8,9,10,11$ & $\begin{array}{l}\text { Zabel et al. 1985; Mucenski et al. } \\
\text { 1988; Moseley and Seldin } 1989\end{array}$ \\
\hline$E m v-27$ & endogenous ecotropic MuLV-27 & 53.6 & C:14 & Taylor and Rowe 1989 \\
\hline$E s-16$ & esterase-16 & 12.1 & $\mathrm{~B}: 13$ & von Diemling et al. $1981,1984,1986$ \\
\hline$E s-26$ & esterase-26 & 37.3 & $\mathrm{~B}: 13$ & $\begin{array}{l}\text { von Diemling et al. 1981, 1984, 1986; } \\
\text { Novak et al. } 1988\end{array}$ \\
\hline Es-27 & esterase-27, serum cholinesterase & 27.3 & $\mathrm{~B}: 13$ & von Diemling et al. 1985,1986 \\
\hline Evi-1 & ecotropic viral integration site-1 & 14.2 & $C: 1,2,8,9,10,12$ & $\begin{array}{l}\text { Copeland et al. 1988; Mucenski et al. } \\
\text { 1988; Moseley and Seldin 1989; } \\
\text { Gisselbrecht et al. 1989; Copeland } \\
\text { and Jenkins 1990 }\end{array}$ \\
\hline Fabpi & $\begin{array}{l}\text { fatty acid binding protein } \\
\text { intestinal }\end{array}$ & 56.6 & C:9 & Sweetser et al. 1987 \\
\hline Fcgrl & high affinity $F c \gamma$ receptor & 46.9 & $C: 1$ & Unpublished data \\
\hline$F g f b^{*}$ & fibroblast growth factor basic & 19.7 & $C: \underline{1}$ & Unpublished data \\
\hline Fgg & $\gamma$ fibrinogen & 46.3 & $C: \overline{8}, 9$ & Blatt et al. 1988 \\
\hline Fim-3 & Friend MuLV integration site- 3 & 14.2 & $C: 3$ & $\begin{array}{l}\text { Sola et al. 1988; Copeland et al. } \\
\text { 1989; Gisselbrecht et al. } 1989\end{array}$ \\
\hline$f t$ & flaky tail & 46.4 & A:5 & Lane 1972; Lane and Eicher 1979 \\
\hline$G b a$ & $\beta$ glucocerebrosidase & 46.6 & C: 1 & $\begin{array}{l}\text { O'Neill et al. 1989; Moseley and } \\
\text { Seldin } 1989 \text { (some of the } G b a \\
\text { assignments were in error; this } \\
\text { position includes the corrected } \\
\text { data) }\end{array}$ \\
\hline$G b p-1$ & $\begin{array}{l}\text { guanine nucleotide-binding } \\
\text { protein-1 }\end{array}$ & 68.3 & $C: 7,13$ & Prochazka et al. 1985 \\
\hline$H-23$ & histocompatibility-23 & 63.6 & B:7,13 & Bailey 1975; Mobraaten et al. 1984 \\
\hline$H-28$ & histocompatibility-28 & 83.3 & $\mathrm{~B}: 7,13$ & Bailey $1975 ;$ Mobraaten et al. 1984 \\
\hline$H-37$ & histocompatibility- 37 & (X) & B:7 & Bailey 1975 \\
\hline $\mathrm{Hao}-2$ & hydroxyacid oxidase-2 (kidney) & 44.0 & $\mathrm{~B}: 3,13$ & $\begin{array}{l}\text { Holmes } 1977 \text { and } 1978 \text {; Gisselbrecht } \\
\text { et al. } 1989\end{array}$ \\
\hline Hist2 & histone gene (2) & $\mathrm{X}$ & C: somatic cell & Graves et al. 1985 \\
\hline$H n l$ & $\begin{array}{l}\text { hypothalamic norepinephrine } \\
\text { level }\end{array}$ & 63.6 & A: congenics & Eleftheriou et al. 1974 \\
\hline$H s p 86-3$ & $\begin{array}{l}\text { heat shock protein } 86 \\
\text { kilodalton-3 }\end{array}$ & $\mathrm{X}$ & C: somatic cell & Moore et al. 1989 \\
\hline If -1 & interferon inducibility locus & 88.6 & A: 7,13 & $\begin{array}{l}\text { De Maeyer et al. 1975; Mobraaten et } \\
\text { al. } 1984\end{array}$ \\
\hline$I l-2$ & interleukin 2 & 8.3 & C: $\underline{4}$, somatic cell & Fiorentino et al. 1989 \\
\hline$(L y-37)$ & see $C d 2$ & & & \\
\hline$(L y-38)$ & see $C d I$ & & & \\
\hline$m a$ & matted & 44.4 & $A: 5,13$ & $\begin{array}{l}\text { Lane 1972; Lane and Eicher } 1979 ; \\
\quad \text { Lane 1980; Mobraaten et al. } 1984\end{array}$ \\
\hline$M m v-2$ & MCF endogenous virus-2 & $\mathrm{X}$ & somatic cell & Hoggan et al. 1986 \\
\hline$M m v-12$ & MCF endogenous virus- 12 & $\mathrm{X}$ & somatic cell & Hoggan et al. 1986 \\
\hline$M o v-10$ & Moloney leukemia virus- 10 & $\mathrm{X}$ & somatic cell & $\begin{array}{l}\text { Jaenisch et al. } 1981 \text {; Munke et al. } \\
1986\end{array}$ \\
\hline$M p m v-9$ & $\begin{array}{l}\text { modified polytropic murine } \\
\text { leukemia virus-9 }\end{array}$ & 92.2 & $C: 6,7,10$ & Frankel et al. 1990 \\
\hline$M p m v-20$ & $\begin{array}{l}\text { modified polytropic murine } \\
\text { leukemia virus- } 20\end{array}$ & 11.3 & $C: 11,12$ & Frankel et al. 1990 \\
\hline my & blebs & 34.4 & A:5 & $\begin{array}{l}\text { Carter 1956; Davisson et al. 1976; } \\
\text { Eicher and Lane } 1980\end{array}$ \\
\hline$N g f b$ & nerve growth factor $\beta$ & 51.4 & $\mathrm{C}: 1,2$ & $\begin{array}{l}\text { Zabel et al. 1984; Dracopoli et al. } \\
\text { 1988; Buchberg et al. 1989; } \\
\text { Kingsmore et al. } 1990\end{array}$ \\
\hline Nras & Nras oncogene & 51.4 & $C: \underline{1}, 2$ & $\begin{array}{l}\text { Ryan et al. 1984; Buchberg et al. } \\
1989\end{array}$ \\
\hline$O d c-3$ & ornithine decarboxylase- 3 & $X$ & $\begin{array}{l}\mathrm{C}: 10 ; \text { proximal } \\
\text { mouse } \mathrm{Chr} 3\end{array}$ & Richards-Smith and Elliott 1984 \\
\hline$o p$ & osteopetrosis & 52.4 & $\mathrm{~A}: 5$ and see $C s f m$ & $\begin{array}{l}\text { Lane and Eicher 1979; Yoshida et al. } \\
1990\end{array}$ \\
\hline Oua-1 & ouabain resistance-1 & $\mathrm{X}$ & A: somatic cell & Kozak et al. 1979 \\
\hline Pgk-lps3 & $\begin{array}{l}\text { phosphoglycerate kinase- } 1 \\
\text { pseudogene } 3\end{array}$ & 9.4 & C: 10, somatic cell & Adra et al. 1988 \\
\hline
\end{tabular}


Table 1. Continued.

\begin{tabular}{|c|c|c|c|c|}
\hline$P k-1$ & $\begin{array}{l}\text { pyruvate kinase (may be the } \\
\text { same as } P k l r \text { ) }\end{array}$ & 37.6 & $\mathrm{~B}: 3$ & $\begin{array}{l}\text { Sola et al. 1988; Gisselbrecht et al. } \\
1989\end{array}$ \\
\hline$P k l r$ & $\begin{array}{l}\text { pyruvate kinase liver, red blood } \\
\text { cells (see } P k-1 \text { ) }\end{array}$ & 46.6 & $\mathrm{C}: 1$ & Unpublished data \\
\hline$P m v-26$ & polytropic murine virus- 26 & 75.8 & $C: 9,12$ & Frankel et al. 1989 \\
\hline Pmv-28 & polytropic murine virus -28 & 46.9 & $\mathrm{C}: 11,12$ & Frankel et al. 1989 \\
\hline$P m v-38$ & polytropic murine virus- 38 & 47.1 & $C: 9,11$ & Frankel et al. 1989 \\
\hline$P m v-39$ & polytropic murine virus-39 & 57.8 & $C: 9,12$ & Frankel et al. 1989 \\
\hline rcm & rostral cerebellar malformation & 69.4 & $\mathrm{~A}: 13$ & Lane et al. 1990 \\
\hline RnuIb-1 & U1b1 small nuclear RNA & 46.7 & $\mathrm{C}: 8$ & Lund et al. 1988 \\
\hline Rnulb-3 & U1b3 small nuclear RNA & 46.9 & $C: 8,10$ & Blatt et al. $1988 ;$ Lund et al. 1988 \\
\hline $\operatorname{soc}$ & soft coat & 47.4 & A:5 & Southard 1971; Eicher and Lane 1980 \\
\hline spa & spastic & 41.4 & A:5 & Lane 1972; Lane and Eicher 1979 \\
\hline sut & subtle gray & 16.2 & A:13 & Lane 1988 \\
\hline Tmevd-2 & $\begin{array}{l}\text { TMEV induced demyelinating } \\
\text { disease susceptibility }\end{array}$ & 8.8 & A:9 & Melvoid et al. 1990 \\
\hline$T s h b$ & $\begin{array}{l}\text { thyrotropin stimulating hormone } \\
\beta \text { subunit }\end{array}$ & 51.4 & $C: 1$ & $\begin{array}{l}\text { Kourides et al. 1984; Naylor et al. } \\
\text { 1986; Dracopoli et al. 1988; } \\
\text { Moseley and Seldin 1989; } \\
\text { Kingsmore et al. } 1990\end{array}$ \\
\hline$V a$ & varitint-waddler & 75.6 & A:5,13 & $\begin{array}{l}\text { Curry 1959; Lane 1972; Lane } 1980 ; \\
\text { Lane and Eicher 1979; Eicher and } \\
\text { Lane 1980; Holmes et al. 1981a } \\
\text { and 1981b; Duley and Holmes } \\
\text { 1982; Mobraaten et al. } 1984\end{array}$ \\
\hline$X m m v-22$ & $\begin{array}{l}\text { xenotropic-MCF leukemia } \\
\text { virus- } 22\end{array}$ & 46.3 & $\mathrm{C}: 9$ & Blatt et al, 1988 \\
\hline$X m m v-47$ & $\begin{array}{l}\text { xenotropic-MCF leukemia } \\
\text { virus- } 47\end{array}$ & 35.0 & $\mathrm{C}: 12$ & Wejman et al. 1985 \\
\hline$X m m v-65$ & $\begin{array}{l}\text { xenotropic-MCF leukemia } \\
\text { virus- } 65\end{array}$ & 46.3 & $C: 9,12,13$ & Wejman et al. 1985 \\
\hline
\end{tabular}

Map positions are based at the centromere (Davisson et al. 1976), and were calculated using data from inbred laboratory strains, interspecific crosses and recombinant inbred strains. Loci which have been assigned to Chr 3 but not regionally mapped are included. Since recombination frequencies may vary depending on the specific cross examined, the composite map positions may distort gene order when loci have not been mapped with respect to each other in an individual backcross, In deriving the composite map, RI strain data was only used to determine gene position as a supplement to backcross data. For a fuller discussion of the considerations applied to generating map positions, the reader is referred to the Mouse Chromosome 1 Committee Report.

${ }^{a}$ Loci in parenthesis indicate loci whose names have been changed. Asterisk indicates provisional designation.

b The map positions are measured in $\mathrm{cM}$ from the centromere. For those loci in which no position can be reasonably assigned, an $\mathrm{X}$ is shown. Parenthesis indicate uncertainty of linkage to mouse Chr 3. "The letters indicate how "alleles" were determined: A, phenotype or biologic property; B, gene product (cell surface antigen, protein electrophoresis etc.); C, RFLVs. For clones used to identify RFLVs the reader should refer to the specific references and/or "List of Mouse DNA Clones and Probes," J.T. Eppig, The Jackson Laboratory.

${ }^{d}$ The numbers refer to the data that were used in addition to specific references to derive the map position (see following). This informa tion is included to supplement the information provided by the references. Numbers are underlined in the table to indicate that unpublished data submitted to the Committee was included in the analysis. 1: complete haplotypes in 114 and incomplete haplotypes in 338 interspecific backcross mice (see specific references and R.J. Oakey and M.F. Seldin, unpublished data); 2: complete haplotypes in 83198 interspecific backcross mice (see specific references); 3 : incomplete haplotypes in 38-74 interspecific backcross mice (see specific references); 4 : complete haplotype data in 92-299 intraspecific backcross (unpublished data kindly provided by $\mathrm{J}$. Todd); 5 : included in nine overlapping three- or four-point crosses that derive from analysis of 125-500 meiotic events in each of multiple individual crosses (specific references); 6: haplotype data in 75 intraspecific backcrosses, W.N. Frankel, unpublished data; 7: CXB strains, see specific references and compiled by D.W. Bailey and currently maintained by B.A. Taylor; 8: AXB and BXA RI strains, see specific references and compiled formerly by $M$. Nesbitt and currently by $B$. Paigen; 9: BXD RI strains, see specific references and compiled by B.A. Taylor; 10: BXH RI strains, see specific references and compiled by B.A. Taylor; 11: AKXD RI strains, see specific references and compiled by B.A. Taylor; 12: AKXL, see specific references and compiled by B.A. Taylor; 13: three-point mapping data, see specific reference in table for data; 14: two-point mapping data, see specific reference in table for data. 
Table 2. Mutant genes on Chr 3. Mapping data for these loci are available in Table 1. Descriptions and additional references can be found in Green (1989).

\begin{tabular}{|c|c|c|}
\hline Symbol & Name & Phenotype \\
\hline$c d m$ & $\begin{array}{l}\text { cadmium } \\
\text { resistance }\end{array}$ & resistance to cadmium induced necrosis of testis \\
\hline $\operatorname{coa}$ & cocoa & pigmentation of coat and eye \\
\hline$d e$ & droopy ear & immature skeleton, disturbed mesenchyme \\
\hline$f t$ & flaky tail & stretched skin, small ears \\
\hline$m a$ & matted & defect of hair cuticle \\
\hline my & blebs & multiple developmental defects \\
\hline$o p, c s f m$ & osteopetrosis & skeletal defects due to defect of macrophage growth factor \\
\hline $\mathrm{rcm}$ & $\begin{array}{l}\text { rostral } \\
\text { cerebellar } \\
\text { malformation }\end{array}$ & $\begin{array}{l}\text { Purkinje and granule cells in anterior lobe of } \\
\text { cerebellum are disorganized; balance defect }\end{array}$ \\
\hline soc & soft coat & abnormal morphology of hair and epidermis \\
\hline spa & spastic & tremor, stiffness, possible glycine receptor deficiency \\
\hline sut & subtle grey & reduction in yellow pigment \\
\hline$v a$ & $\begin{array}{l}\text { varitint } \\
\text { waddler }\end{array}$ & $\begin{array}{l}\text { complex phenotype with behavioral, hearing, and } \\
\text { pigmentation abnormalities }\end{array}$ \\
\hline
\end{tabular}

Table 3. Reference loci for Chr 3.

\begin{tabular}{|c|c|c|c|c|c|c|c|}
\hline Locus & $\begin{array}{l}\text { Map } \\
\text { Position }\end{array}$ & & $\begin{array}{l}\text { RFLV } \\
\text { Probe }\end{array}$ & $\begin{array}{l}\text { PCR } \\
\text { Product }\end{array}$ & $\begin{array}{l}\text { PCR } \\
\text { Variant }\end{array}$ & $\begin{array}{l}{ }^{\circ} \mathrm{C}, \mathrm{Mg}^{++} \\
\text {cycles }\end{array}$ & PCR Primer Sequences \\
\hline & GBASE & Fig.1 & & & & & \\
\hline Car-1 & 4 & 5 & $\begin{array}{l}\text { Venta et al. } \\
1985\end{array}$ & $220 \mathrm{bp}$ & Hha I site & $\begin{array}{l}59^{\circ}, 1.5 \\
40 \text { cyc }\end{array}$ & $\begin{array}{l}\text { 1 - CAT TTC CGT ACGT CTG AAC TT } \\
\text { 2- GAG TCG GGA TCC AAA TCA CC }\end{array}$ \\
\hline$I l-2$ & - & 8 & $\begin{array}{l}\text { Fiorentino } \\
\text { et al. } 1989\end{array}$ & $130 \mathrm{bp}$ & $(\mathrm{CAG})_{n}$ & $55^{\circ}, 1$ & $\begin{array}{l}\text { 1 - GTG CTC CTT GTC AAC AGC GCA } \\
2 \text { - CTC CTG TAG GTC CAT CAA CAG C }\end{array}$ \\
\hline Gba & 52 & 46 & $\begin{array}{l}\text { ONeill } \\
\text { et al. } 1989\end{array}$ & - & - & - & - \\
\hline$A m y-1$ & 68 & 49 & $\begin{array}{l}\text { Wiebauer } \\
\text { et al. } 1985\end{array}$ & $190 \mathrm{bp}$ & $(\mathrm{CA})_{n}$ & $50^{\circ}, 2$ & $\begin{array}{l}\text { 1-GAA CAT ATG TGT AAG TAA AAT GTAC } \\
2 \text { - GAT TTT AAT TCA TTA ATT AAG GGT TAG }\end{array}$ \\
\hline Adh-1 & 83 & 67.5 & $\begin{array}{l}\text { Ceci et al. } \\
1987\end{array}$ & $330 \mathrm{bp}$ & - & $\begin{array}{l}55^{\circ}, 2 \\
40 \text { cyc }\end{array}$ & $\begin{array}{l}\text { 1-CTT ACT GGG TGA CAT AGA CG } \\
2 \text { - CCT TTC ATC CAT GTA CAT ATA C }\end{array}$ \\
\hline
\end{tabular}

These loci can be typed by Southern blot or by PCR. Map positions from the new composite map in Fig. 1 and from GBASE, the on-line database of The Jackson Laboratory, are given. The order of these loci is the same on both maps, and any gene on Chr 3 is expected to be within 20 or $30 \mathrm{cM}$ of one of these markers. For additional sources of these probes, see "List of Mouse DNA Clones and Probes," J.T. Eppig, The Jackson Laboratory. Primer sequences were kindly made available prior to publication by P.J. Venta ( $\mathrm{Car}$ 2), J. Todd, C. Hearne (Adh-1 and $I l-2)$, and M. Meisler (Amy-1). PCR conditions are: temperature of annealing, ${ }^{\circ} \mathrm{C} ; \mathrm{Mg}^{++}, \mathrm{mM} ; \mathrm{cyc}$, number of cycles. The Car-2 PCR product must be digested with $H h a$ I to detect genetic variation among strains. The $A m y-I$ primers amplify a spretus fragment which differs from the inbred strains tested; there is no amplified product from C57BL/6J. 


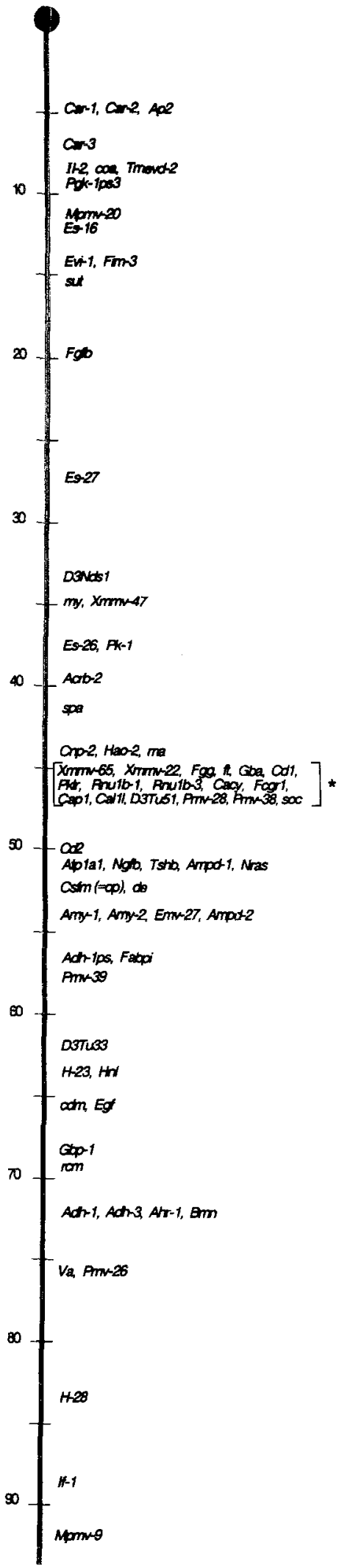

Fig. 1. Composite map of $\mathrm{Chr} 3$. The map is based at the centromere (Davisson et al. 1976). Linkage data and locus names are provided in Table 1. Loci that have been assigned to Chr 3 but not regionally mapped can also be found in Table $1 .{ }^{*}$ Loci within the bracket are located between $46-47 \mathrm{cM}$ on the map; gene order not indicated.
The carbonic anhydrase gene cluster on proximal $\mathrm{Chr} 3$ is also organized differently in human and mouse. The three human carbonic anhydrase genes are localized within $180 \mathrm{~kb}$ with the gene order Car1-Car-3-Car-2 (Tashian et al. 1990). In the mouse, Car-3 is reported to be $>1 \mathrm{cM}$ distal to the other two genes (Beechey et al. 1990).

\section{Mutant genes mapped to Chr 3}

The spontaneous mutant $o p$, osteopetrosis, has a recessive skeletal defect which includes a doomed skull and accumulation of bone which lacks marrow cavities (Green 1989). The close linkage of $o p$ and the Csfm gene encoding a macrophage colony stimulating factor led to the demonstration of a single base pair (bp) insertion in the coding region of $\mathrm{Cs} f \mathrm{fm}$ in the op mutant (Yoshida et al. 1990). Other mutant genes which have been mapped to Chr 3 are listed in Table 2. With the exception of $o p$, the molecular basis for these interesting phenotypes remains to be discovered.

\section{Reference loci for Chr 3}

Incorporation of a common set of reference loci into future crosses will greatly facilitate the growth of composite genetic maps by providing the basis for direct comparison among crosses. Towards this end, we recommend that the following five loci be included in future crosses: Car-1, Il-2, Gba, Amy-1 and Adh-1. These loci span the chromosome, so that any gene on Chr 3 is expected to be within 20 or $30 \mathrm{cM}$ of a marker. Cloned probes for these loci which detect RFLVs are available, and PCR primers which detect some genetic variation are available for four of these markers (Table 3 ). We are grateful to colleagues for providing unpublished primer sequences.

Acknowledgments. We thank Donald Doolittle, The Jackson Laboratory, for providing the GBASE list of Chr 3 loci. Unpublished primer sequences were generously provided by John Todd and Kate Hearne (Oxford University) and Patrick Venta and Richard Tashian (University of Michigan). We are grateful to Linda Samuelson for computer generation of Fig. 1.

\section{References}

Adra, C.N., Ellis, N.A., and McBurney, M.W.: The family of mouse phosphoglycerate kinase genes and pseudogenes. Somat Cell Molec Genet 14: 69-81, 1988.

Balak, K.J., Keith, R.H., and Felder, M.F.: Genetic and developmental regulation of mouse liver alcohol dehydrogenase. J Biol Chem 257: 15000-15007, 1982.

Beechey, C.V. and Searle, A.G.: Position of $V a$ and $m a$ on chr. 3. Mouse News Lett 62: 52, 1980.

Beechey, C., Tweedie, S., Spurr, N., Ball, S., Peters, J., and Edwards, Y.: Mapping of mouse carbonic anhydrase-3, Car-3; another locus in the homologous region of mouse chromosome 3 and human chromosome 8. Genomics 6: 692-696, 1990.

Bernier L., Coleman, D.R., and D'Eustachio, P.: Chromosomal locations of genes encoding $2^{\prime}, 3^{\prime}$ cyclic nucleotide $3^{\prime}$-phosphodiesterase and glial fibrillary acidic protein in the mouse. $J$ Neurosci Res 20: 496-504, 1988. 
Bessis, A., Simon-Chazottes, D., Devillers-Thiery, A., Guénet, J.L., and Changeux, J.-P.: Chromosomal localization of the mouse genes coding for $\alpha 2, \alpha 3, \alpha 4$, and $\beta 2$ subunits of neuronal nicotinic acetylcholine receptor. FEBS Lett 264: 48-52, 1990.

Blatt, C., Saxe, D., Marzluff, W.F., Lobo, S., Nesbitt, M.N., and Simon, M.T.: Mapping and gene order of U1 small nuclear RNA, endogenous viral env sequence, amylase, and alcohol dehydrogenase-3 on mouse chromosome 3. Som Cell Mol Genet 14: 133-142, 1988

Bloor, J.H. and Meisler, M.H.: Additional evidence for the close linkage of Amy-I and Amy-2 in the mouse. J Hered 7I: 449-451, 1980.

Bonhomme, F., Bemehdi, F., Britton-Davidian, J., and Martin, S.: Analyse genetique de croisement interspecifiques $M u s$ musculus L. $\times$ Mus spretus Lataste: Liason de Adh-I avec Amy-1 sur le chromosome 3 et de $E s-14$ avec Mod-1 sur le chromosome 9. DR Acad Sci Paris 289: 545-548, 1979.

Brooks, B., Johnson, B., Heinzmann, C., Mohandas, T., Sparkes, R., Jones, S., Bennett, P., Balacs, T., Moore, G., Conley, L., and Hankinson, O.: Abstract: Localization of a gene required for the nuclear translocation of the dioxin receptor to human chromosome 1 and mouse chromosome 3 and a human RFLP with Msp I. Amer J Hum Genet 45: 132, 1989.

Buchberg, A.M., Jenkins, N.A., and Copeland, N.G.: Localization of the murine macrophage colony-stimulating factor to chromosome 3 using interspecific backcross analysis. Genomics 5: 363$367,1989$.

Carter, T.C.: Genetics of the little and Bagg X-rayed mouse stock. J Genet 54: 311-326, 1956.

Ceci, J.D., Zheng, Y.-W., and Felder, M.R.: Molecular analysis of mouse alcohol dehydrogenase: Nucleotide sequence of the $a d h-1$ gene and genetic mapping of a related nucleotide sequence to Chromosome 3. Gene 59: 171-182, 1987.

Chapman, V.M., Blaird, R.J., Murawski, M., and Quarantillo, B.A.: Electrophoretic variation for alcohol dehydrogenase $A D H$ 1. Mouse News Lett 61: 60, 1979.

Clayton, L.K., Ramachandran, H., Pravtcheva, D., Chen, Y.-F., Diamond, D.J., Ruddle, F.H., and Reinherz, E.L.: The gene for T11 (CD2) maps to chromosome 1 in humans and to chromosome 3 in mice. J Immunol 140: 3617-3621, 1988.

Copeland, N.G., Buchberg, A.M., Gilbert, D.J., and Jenkins, N.A.: Recombinant inbred mouse strains: Models for studying the molecular genetic basis of myeloid tumorigenesis. Curr Topic Microbiol Immunol 149: 45-56, 1989.

Copeland, N.G. and Jenkins, N.A.: Retroviral integration in murine myeloid tumors to identify Evi-1, a novel locus encoding a zincfinger protein. Adv Cancer Res 54: 141-157, 1990.

Curry, G.A.: Genetical and developmental studies on droopy-eared mice. J Embryol Exp Morphol 7: 39-65, 1959.

Czosnek, H., Nudel, U., Shani, M., Barker, P.E., Pravtcheva, D.D., Ruddle, F.H., and Yaffe, D.: The genes coding for the muscle contractile proteins, myosin heavy chain, myosin light chain 2, and skeletal muscle actin are located on three different mouse chromosomes. EMBO J 1: 1299-1305, 1982.

Czosnek, H., Nudel, U., Mayer, Y., Barker, P.E., Pravtcheva, D.D., Ruddle, F.H., and Yaffe, D.: The genes coding for the cardiac muscle actin, the skeletal muscle actin and the cytoplasmic b-actin are located on three different mouse chromosomes. EMBO J 2: 1977-1979, 1983.

Davisson, M.T., Eicher, E.M., and Green, M.C.: Genes on chromosome 3 of the mouse. J Hered 67: 155-156, 1976.

DeMaeyer, E., DeMaeyer-Guignard, J., and Bailey, D.W.: Effect of mouse genotype on interferon production. I. Lines congenic at the If-1 locus. Immunogenetics, 1: 438-443, 1975.

Dracopoli, N.C., Rose, E., Whitfield, G.K., Guidon, P.T., Jr., Bale, S.J., Chance, P.A., Kourides, I.A., and Housman, D.E.: Two thyroid hormone regulated genes, the beta-subunits of nerve growth factor (NGFB) and thyroid stimulating hormone (TSHB), are located less than $310 \mathrm{~kb}$ apart in both human and mouse genomes. Genomics 3: 161-167, 1988.

Duley, J.A. and Holmes, R.S.: Biochemical genetics of aldehyde reductase in the mouse: $A h r-l-a$ new locus linked to the alcohol dehydrogenase gene complex on chromosome 3. Biochem Genet 20: $1067-1083,1982$.

Eicher, E.M., Stern, R.H., Womack, J.E., Davisson, M.T., and
Roderick, T.H.: Evolution of mammalian carbonic anhydrase loci by tandem duplication: Close linkage of Car-1 and Car-2 to the centromere region of chromosome 3 of the mouse. Biochem Genet 14: 651-660, 1976.

Eicher, E.M. and Lane, P.W.: Assignment of LGXVI to chromosome 3 in the mouse. $J$ Hered 71:315-318, 1980.

Eleftheriou, B.E.: A gene influencing hypothalamic norepinephrine levels in mice. Brain Res 70: 538-540, 1974.

Fiorentino, L., Austen, D., Pravtcheva, D., Ruddle, F.H., and Brownell, E.: Assignment of the interleukin-2 locus to mouse Chromosome 3 in a region homologous to human chromosome $4 \mathrm{q}$. Genomics 5: 651-653, 1989.

Frankel, W.N., Stoye, J.P., Taylor, B.A., and Coffin, J.M.: Genetic identification of endogenous polytropic proviruses by using recombinant inbred mice. $J$ Virol 63: 3810-3821, 1989.

Frankel, W.N., Stoye, J.P., Taylor, B.A., and Coffin, J.M.: A linkage map of endogenous murine leukemia proviruses. Genetics 124: 221-236, 1990 .

Gisselbrecht, S., Sola, B., Fichelson, S., Bordereaux, D., Tambourin, P., Mattei, M.-G., Simon, D., and Guénet, J.-L.: The murine M-CSF gene is localized on chromosome 3. Blood 73: $1742-1745,1989$.

Graves, R.A., Wellman, S.E., Chiu, I.-M., and Marzluff, W.F.: Differential expression of two clusters of mouse histone genes. $J$ Mol Biol 183: 179-194, 1985.

Green, M.C.: In M.F. Lyon and A.G. Searle (eds.); Genetic Variants and Strains of the Laboratory Mouse, Second Edition, Oxford University Press, New York, 1989.

Heuckeroth, R.O., Birkenmeier, E.H., Levin, M.S., and Gordon, J.I.: Analysis of the tissue-specific expression, developmental regulation, and linkage relationships of a rodent gene encoding heart fatty acid binding protein. $J$ Biol Chem 262: 9709-9717, 1987.

Hoggan, M.D., O'Neill, R.R., and Kozak, C.A.: Nonecotropic murine leukemia viruses in $\mathrm{BALB} / \mathrm{c} B x v-1$ provirus and the single NFS endogenous xenotrope. $J$ Virol 60: 980-986, 1986.

Holmes, R.S.: The genetics of $\alpha$-hydroxy acid oxidase and alcohol dehydrogenase in the mouse: Evidence for multiple gene loci and linkage between Hao-2 and Adh-3. Genetics 87: 709-716, 1977.

Holmes, R.S.: Genetics of hydroxyacid oxidase isozymes in the mouse. Localisation of $\mathrm{Hao}-2$ on linkage group XVI. Heredity 41 . 403-406, 1978.

Holmes, R.S.: Genetics and ontogeny of alcohol dehydrogenase isozymes in the mouse: Evidence for a cis-acting regulator gene (Adt-1) controlling $\mathrm{C} 2$ isozyme expression in reproductive tissues and close linkage of $A d h-3$ and $A d t-1$ on chromosome 3. Biochem Genet 17: 461-472, 1979.

Holmes, R.S., Albanese, R., Whitehead, F.D., and Duley, J.A.: Mouse alcohol dehydrogenase isozymes: Products of closely localized duplicated genes exhibiting divergent kinetic properties. $J$ Exp Zool 217: 151-157, 1981a.

Holmes, R.S., Andrews, S.J., and Beechey, C.V.: Genetic regulation of alcohol dehydrogenase $\mathrm{C} 2$ in the mouse. Developmental consequences of the temporal locus $(A d h-3 t)$ and positioning of Adh-3 on chromosome 3. Devel Genet 2: 89-98, 1981b.

Holmes, R.S., Andrews, S.J., Beechey, C.V.: Alcohol dehydrogenase C2 (stomach enzyme). Mouse News Lett 64: 54, 1981c.

Holmes, R.S. and Duley, J.A.: Alcohol dehydrogenase isozymes (Adh-1 and Adh-3 on chromosome 3). Mouse News Lett 66: 60, 1982.

Holmes, R.S., Duley, J.A., and Imai, S.: Alcohol dehydrogenase temporal locus (Adh-1t). Mouse News Lett 68: 67, 1983.

Holmes, R.S., Mather, P.B., and Duley, J.A.: Gene markers for alcohol-metabolizing enzymes among recombinant inbred strains of mice with differential behavioural responses toward alcohol. Anim Blood Groups Biochem Genet 16: 51-59, 1985.

Howard, T.A., Rochelle, J.M., Saunders, A.M., and Seldin, M.F.: A linkage map of mouse chromosome 8: Further definition of the syntenic relationship between mouse chromosome 8 and human chromosomes 8,16 and 19. Genomics, in press, 1991.

Jaenisch, R., Jahner, D., Nobis, P., Simon, I., Lohler, J., Harbers, K., and Grotkopp, D.: Chromosomal position and activation of retroviral genomes inserted into the germ line of mice. Cell 24 : 519-529, 1981.

Kent, R.B., Fallows, D.A., Geissler, E., Glaser, T., Emanuel, J.R., 
Lalley, P.A., Levenson, R., and Housman, D.E.: Genes encoding $\alpha$ and $\beta$ subunits of $N a$, K-ATPase are located on three different chromosomes in the mouse. Proc Natl Acad Sci USA 84: 5369 $5373,1987$.

Kingsmore, S.F., Moseley, W.S., Watson, M.L., Sabina, R.L., Holmes, E.W., and Seldin, M.F.: Long-range restriction site mapping of a syntenic segment conserved between human chromosome 1 and mouse chromosome 3. Genomics 7: 75-83, 1990.

Kourides, I.A., Barker, P.E., Gurr, J.A., Pravtcheva, D.D., and Ruddle, F.H.: Assignment of the genes for the $\alpha$ and $\beta$ subunits of thyrotropin to different mouse chromosomes. Proc Natl Acad SCi USA 81: 517-519, 1984.

Kozak, C.A., Fournier, R.E.K., Leinwand, L.A., and Ruddle, F.H.: Assignment of the gene controlling cellular ouabain resistance to Mus musculus chromosome 3 using human/mouse microcell hybrids. Biochem Genet 17: 23-34, 1979.

Lane, P.W.: Two new mutations in linkage group XVI of the house mouse, Flaky tail and varitint-waddler-J. $J$ Hered 63: 135-140, 1972.

Lane, P.W. and Eicher, E.M.: Gene order in linkage group XVI of the house mouse. $I$ Hered 70: 239-244, 1979.

Lane, P.W.: Chromosome 3 position of de. Mouse News Lett 62: 56, 1980.

Lane, P.W.: Subtle gray (sut); small with kinky tail (skt). Mouse News Lett 80: 165, 1988.

Lane, P.W., Bronson, R., and Spencer, C.: Rostral cerebellar malformation. Mouse Genome 86: 237, 1990.

Lund, E. and Nesbitt, M.N.: The embryonic and adult mouse U1 snRNA genes map to different chromosomal loci. Som Cell Mol Genet 14: 143-148, 1988.

Lundin, L.-G.: A gene $(B m n)$ controlling $\beta$-mannosidase activity in the mouse is located in the distal part of chromosome 3. Biochem Genet 25: 603-610, 1987.

Marks, S.C., Jr. and Lane, P.W.: Osteopetrosis, a new recessive skeletal mutation on chromosome 12 of the mouse. $J$ Hered 67 : 11-18, 1976.

Melvold, R.W., Jokinen, D.M., Miller, S.D., Dal Canto, M.C., and Lipton, H.L.: Identification of a locus on mouse chromosome 3 involved in differential susceptibility to Theiler's murine encephalomyelitis virus-induced demyelinating disease. $J$ Virol 64: 686$690,1990$.

Mobraaten, L., Bunker, H.P., DeMaeyer-Guignard, J., DeMaeyer, E., and Bailey, D.W.: Location of histocompatibility and interferon loci on chromosome 3 of the mouse. $J$ Hered 75: 233-234, 1984.

Moore, S.K., Kozak, C., Robinson, E.A., Ullrich, S.J., and Appella, E.: Murine 86 and $84 k D a$ heat shock proteins, cDNA sequences, chromosome assignments and evolutionary origins. $J$ Biol Chem 264: 5343-5351, 1989.

Moseley, W.S. and Seldin, M.F.: Definition of mouse chromosome 1 and 3 gene linkage groups that are conserved on human chromosome 1: Evidence that a conserved linkage group spans the centromere of human chromosome 1. Genomics 5:899-905, 1989.

Moseley, W.S., Watson, M.L., Kingsmore, S.F., and Seldin, M.F.: CD1 defines conserved linkage group border between human chromosome 1 and mouse chromosomes 1 and 3. Immunogenetics 30: 378-382, 1989.

Moseley, W.S., Morisaki, T., Sabina, R.L., Holmes, E.W., and Seldin, M.F.: Ampd-2 maps to distal mouse chromosome 3 in linkage with ampd-1. Genomics 6: 572-574, 1990.

Mucenski, M.L., Taylor, B.A., Copeland, N.G., and Jenkins, N.A.: Chromosomal location of Evi-I, a common site of ecotropic viral integration in AKXD murine myeloid tumors. Oncogene Res 2: 219-233, 1988.

Munke, M., Harbers, K., Jaenisch, R., and Francke, U.: Chromosomal mapping of four different integration sites of Moloney murine leukemia virus including the locus for $\alpha 1(\mathrm{I})$ collagen in mouse. Cytogenet Cell Genet 43: 140-149, 1986.

Naylor, S.L., Sakaguchi, A.Y., McDonald, L., Todd, S., Lalley, P.A., Shows, T.B., and Chin, W.W.: Mapping thyrotropin $\beta$ subunit gene in man and mouse. Somat Cell Mol Genet 12: 307-311, 1986.

Novak, E., Sweet, H.O., Prochazka, M., Parentis, M., Sobel, R., Reddington, M., Cairo, A., and Swank, R.T.: Cocoa: A new mouse model for platelet storage pool deficiency. Br J Hemato 69: 371-378, 1988.

O'Neill, R.R., Tokoro, T., Kozak, C.A., and Brady, R.O.: Comparison of the chromosomal localization of murine and human glucocerebrosidase genes and of the deduced amino acid sequences. Proc Natl Acad Sci USA 86: 5049-5053, 1989.

Paul, P.R. and Elliott, R.W.: Analysis of the mouse Amy locus in recombinant inbred mouse strains. Biochem Genet 25: 569-579, 1987.

Prochazka, M., Staeheli, P., Holmes, R.S., and Haller, O.: Interferon-induced guanylate-binding proteins: Mapping of the murine Gbp-1 locus to chromosome 3. Virology 145: 273-279, 1985

Richards-Smith, B. and Elliott, R.W.: Mapping of a family of repeated sequences in the mouse genome. Mouse News Lett 71 : $46-47,1984$

Ryan, J., Hart, C.P., and Ruddle, F.H.: Molecular cloning and chromosome assignment of murine N-ras. Nucl Acids Res 12: 60636072, 1984.

Samuelson, L.C., Wiebauer, K., Snow, C.M. and Meisler, M.H.: Retroviral and pseudogene insertion sites reveal the lineage of human salivary and pancreatic amylase genes from a single gene during primate evolution. Mol Cell Biol 10: 2513-2520, 1990.

Saris, C.J.M., Kristensen, T., D'Eustachio, P., Hicks, L.J., Noonan, D.J., Hunter, T., and Tack, B.F.: cDNA sequence and tissue distribution of the mRNA for bovine and murine p11, the S100-related light chain of the protein-tyrosine kinase substrate p36 (Calpactin I). J Biol Chem 262: 10663-10671, 1987.

Sewell, W.A., Brown, M.H., Owen, M.J., Fink, P.J., Kozak, C.A., and Crumpton, M.J.: The murine homologue of the T lymphocyte CD2-antigen: Molecular cloning, chromosome assignment and cell surface expression. Europ J Immunol 17: 1015-1020, 1987.

Sola, B., Simon, D., Mattei, M.-G., Fichelson, S., Bordereaux, D., Tambourin, P.E., Guénet, J.-L., and Gisselbrecht, S.: Fim-1, Fim-2/c-fms, and Fim-3, three common integration sites of Friend murine leukemia virus in myeloblastic leukemias, map to mouse chromosomes 13, 18, and 3, respectively. $J$ Virol 62: 3973-3978, 1988 .

Southard, J.L.:: Soft coat and hemimelic extra toes. Mouse News Lett 45: 29, 1971

Sweet, H.O. and Prochazka, M.: Cocoa (coa). Mouse News Lett 73 . $18,1985$.

Sweetser, D.A., Birkenmeier, E.H., Klisak, I.J., Zollman, S., Sparkes, R.S., Mohandas, T., Lusis, A.J., and Gordon, J.I.: The human and rodent intestinal fatty acid binding protein genes. A comparative analysis of their structure, expression, and linkage relationships. J Biol Chem 262: 16060-16071, 1987.

Tashian, R.E., Venta, P.J., Nicewander, P.H., and HewettEmmett, D.: Evolution, structure, and expression of the carbonic anhydrase multigene family. In Isozymes: Structure, Function, and Use in Biology and Medicine, Wiley-Liss, Inc., pp. 159-175, 1990.

Taylor, B.A., Heiniger, H.J., and Meier, H.: Genetic analysis of resistance to cadmium-induced testicular damage in mice. Proc Soc Exp Biol Med 143: 629-633, 1973.

Taylor, B.A. and Rowe, I.: A mouse linkage testing stock possessing multiple copies of the endogenous ecotropic murine leukemia virus genome. Genomics 5: 221-232, 1989.

van Heyningen, V., Emslie, E., and Dorin, J.F.: Abstract: Related calcium binding proteins map to the same sub-region of chromosome 1q and to a probable region of homology on mouse chromosome 3. Cytogenet Cell Genet 51: 1095, 1989.

Venta, P.J., Montgomery, J.C., Hewett-Emmett, D., Wiebauer, K., and Tashian, R.E.: Structure and exon to protein domain relationships of the mouse carbonic anhydrase II gene. $J$ Biol Chem 260: 12130-12135, 1985 .

Vincek, V., Kawaguchi, H., Mizuno, K., Zaleska-Rutczynska, Z., Kasahara, M., Forejt, J., Figueroa, F., and Klein, J.: Linkage map of mouse chromosome 17: Localization of 27 new DNA markers, Genomics 5: 773-786, 1989.

von Deimling O.H. and Otto, J.: Esterase-16 on chromosome 3. Mouse News Lett 64: 52, 1981.

von Deimling, O.H., Schupp, P., and Otto, J.: Esterase-16 (Es-16): Characterization, polymorphism and linkage to chromosome 3 of kidney esterase locus of the house mouse. Biochem Genet 19 . 1091-1099, 1981. 
von Deimling, O.H., Wassmer, B., and Muller, M.: Esterase-26 (ES-26): Characterization and genetic location on chromosome 3 of an eserine-sensitive esterase of the house mouse (Mus musculus). Biochem Genet 22: 1119-1126, 1984.

von Deimling, O.H.: EST-A. Mouse News Lett 73: 15, 1985.

von Deimling, O.H.: Esterase 27. Mouse News Lett 74: 89, 1986. Weiman, J.C., Taylor, B.A., Jenkins, N.A., and Copeland, N.G.: Endogenous xenotropic murine leukemia virus-related sequences map to chromosomal regions encoding mouse lymphocyte antigens. $J$ Virol 50: 237-247, 1989.

Wiebauer, K., Gumucio, D.L., Jones, J.M., Caldwell, R.M., Hartle, H.T., and Meisler, M.H.: A 78-kilobase region of mouse chromosome 3 contains salivary and pancreatic amylase genes and a pseudogene. Proc Natl Acad Sci USA 82: 5446-5449, 1985.
Yoshida, H., Hayaski, S.-I., Kunisada, T., Ogawa, M., Nishikawa, S., Okamura, H., Sudo, T., Shultz, L.D., and Nishikawa, S.-I.: The murine mutation osteopetrosis is in the coding region of the macrophage colony stimulating factor gene. Nature 343: 442-443, 1990.

Zabel, B.U., Sakaguchi, A.Y., Lalley, P.A., Scott, J., and Naylor, S.L.: Abstract: The nerve growth factor $(\mathrm{Ngf})$ gene is on mouse chromosome 3. Cytogenet Cell Genet 37: 614, 1984.

Zabel, B.U., Eddy, R.L., Lalley, P.A., Scott, J., Bell, G.I., and Shows, T.B.: Chromosomal locations of the human and mouse genes for precursors of epidermal growth factor and the $\beta$ subunit of nerve growth factor. Proc Natl Acad Sci USA 82: 469-473, 1985. 